\title{
REVIEW
}

\section{The Possible Importance of Silicon in Marine Eutrophication}

\author{
C. B. Officer ${ }^{1}$ and J. H. Ryther ${ }^{2}$ \\ 1 Earth Sciences Department, Dartmouth College, Hanover, New Hampshire 03755, USA \\ 2 Woods Hole Oceanographic Institution, Woods Hole, Massachusetts 02543, USA
}

\begin{abstract}
Diatom phytoplankton populations are the usual food for zooplankton and filter feeding fishes and contribute in a direct way to the large fishable populations in coastal zones. Flagellates, on the other hand, are frequently poor foods for most grazers and can lead to undesirable eutrophication effects. Arguments are presented that silicon is often the controlling nutrient in altering a diatom to a flagellate community. The alteration is governed by the relative magnitudes of the natural fluxes of the nutrients nitrogen, phosphorus and silicon to the receiving water body and the recycled fluxes of nitrogen and phosphorus from zooplankton grazing and phytoplankton respiration and decomposition. Examples of such alterations are presented for oceanic, estuarine and inland water bodies.
\end{abstract}

\section{THESIS}

We can delineate several phytoplankton-based ecosystems in the coastal zone which may be altered by human introduction of nutrients and other biostimulatory chemicals into the ocean. Two such systems are of particular importance. One is the ecosystem dominated by diatoms which are the usual food for filter feeding fishes and zooplankton and contribute in a direct way to the large fishable populations in coastal zones. Diatoms grow very rapidly, have short lifetimes, are grazed heavily, and are rarely a nuisance. The other is the nondiatom ecosystem usually dominated by flagellates, including dinoflagellates, chrysophytes, chlorophytes and coccolithophoridae, though it also may contain large proportions of nonmotile green and bluegreen algae, particularly in brackish and estuarine environments. For convenience, the latter will be referred to here as the 'flagellate' ecosystem. Flagellates persist for longer periods of time, many are known to be poor foods for most grazers, and the motile species are able to concentrate to undesirable concentrations due to their ability to swim and respond to light. Certain dinoflagellate epidemics, for example, are serious pollution events that must be understood to be predicted and controlled.
To our knowledge all excessive marine phytoplankton growths which have led to undesirable eutrophication effects have been related to flagellate blooms. These eutrophication effects can take several forms. One, the excessive growth, which is not grazed, can lead to oxygen deficiencies when the organic particulate matter sinks and subsequently consumes oxygen by respiration and decay. Such anoxic conditions can lead directly to fish and shellfish kills. Two, the toxic dinoflagellates, including some red tides, can adversely effect the marine ecosystem and can poison man through the consumption of shellfish which have filtered out the toxic components. Three, the flagellate blooms can reach proportions which discolor the water and make it unsightly and malodorous, reducing its esthetic and recreational value.

In general, diatoms are able to grow at least as rapidly as other kinds of unicellular algae (Jitts et al., 1964; Thomas et al., 1978; Brand, 1979). A reasonable question, then, is what environmental conditions will lead to a flagellate growth dominant over a diatom growth. Several possibilities exist, which include initial seed population, trace elements and chemicals, sinking and motility, preferential grazing, and nutrient concentrations. We should like to discuss one such possibility - the importance of the nutrient silicon. 
Diatoms require the major nutrients nitrogen, phosphorus and silicon for their photosynthesis; diatoms use silicon in approximately a one-to-one atomic ratio with nitrogen (Redfield et al., 1963). The flagellates associated with coastal eutrophication effects need only nitrogen and phosphorus, together with the trace elements and micronutrients that all autotrophs require.

In temperate latitudes silicon in the form of dissolved silicate is usually supplied in plentiful amounts through land weathering to the estuarine and coastal zones. Nitrogen and phosphorus are also available from river runoff inputs including sewage, industrial and agricultural sources. When the solar conditions are appropriate, which usually occurs in late spring or early summer but also in midwinter in some shallow estuaries, a common event is a diatom dominated bloom. The organic nitrogen and phosphorus components of the diatoms will be recycled rapidly back to an inorganic form through zooplankton grazing, depending on the size of the bloom and the zooplankton population, and through respiration and decay. The silicon is largely confined to the tests, skeletal material, of the diatoms. The animals which feed on the diatoms have no use for silicon and reject it directly. The tests dissolve and recycle silicon at a much slower rate than the organic nitrogen and phosphorus components. We may, then, expect following the initial diatom bloom period that a new nutrient pool will be produced which is rich in inorganic nitrogen and phosphorus but depleted in silicon. The relative amount of silicon depletion in this second nutrient pool will, of course, also depend on the amounts and rate process relations between the organic nutrient cycling and the continuing river nutrient inputs. We now have conditions suitable for a flagellate bloom, and depending on the nutrient levels this could lead to an excessive, eutrophic, growth

This sequence of events from a late spring-early summer diatom dominated bloom to a later summerearly fall flagellate dominated bloom is a common occurrence in temperate coastal waters (Margalef, 1958). We suggest that this sequence from one population to the other is controlled by the silicon regeneration cycle.

Also, it is important to note that sewage effluents which invariably contain high nitrogen and phosphorus nutrient levels usually do not have a corresponding level of silicon, i. e. equivalent to nitrogen, as required by diatoms. Table 1 is a summary of observed secondary sewage effluents for the East Coast of the United States. The silicon levels are principally determined by the land weathered, municipal water input levels. We would, then, expect that increased sewage inputs, whether primary or secondary treated, to a
Table 1. Concentrations of inorganic nitrogen $\left(\mathrm{NH}_{4}^{+}+\mathrm{NO}_{2}^{-}+\mathrm{NO}_{3}^{-}\right)$, silicon $\left(\mathrm{SiO}_{3}^{\overline{1}}\right)$ and phosphorus $\left(\mathrm{PO}_{4}^{\overline{5}}\right)$, and $\mathrm{N}: \mathrm{Si}$ ratios in secondary sewage effluent $\left(\mu \mathrm{gAl}^{-1}\right)$. Sources: (1) Garside et al. (1976), (2) Dunstan and Tenore (1972), (3) Ryther (1977)

\begin{tabular}{|lrrrr|}
\hline \multicolumn{1}{|c}{ Locations } & N & Si & P & N:Si \\
\hline Tallman Island, NY (1) & 1200 & 80 & 130 & $15: 1$ \\
Cranston, RI (2) & 2166 & 110 & 213 & $20: 1$ \\
Warwick, RI (2) & 1342 & 100 & 295 & $13: 1$ \\
Plymouth, MA (2) & 1176 & 70 & 243 & $17: 1$ \\
Otic AFB, MA (2) & 1265 & 110 & 264 & $11: 1$ \\
Wareham, MA (3) & 1205 & 173 & 142 & $7: 1$ \\
\hline
\end{tabular}

confined estuarine or coastal water body could lead not only to an increased plankton bloom but also to a change in the initial blooms from a diatorn to a flagellate dominated population.

\section{CONCEPTUAL RELATIONS}

The proposed nutrient cycle relations for a diatom bloom followed by a flagellate bloom are shown in Figure 1. In the discussion above we have considered a riverine source of nutrients, which is the usual case in coastal eutrophication. We could alternatively have considered an oceanic source either of a continuous or an intermittent nature related to coastal upwelling or seasonal overturn, as shown in the figure.

The fluxes, as shown by the arrows in the figure, depend both on the magnitude, or concentration level, of the nutrient involved in the given process and the

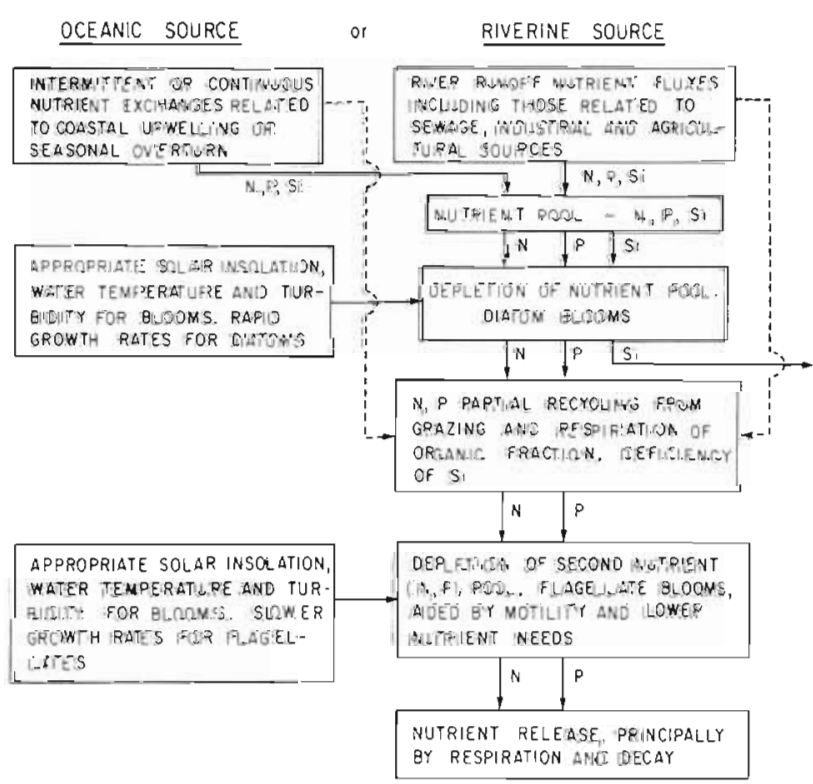

Fig. 1. Proposed nutrient $(N, P, S i)$ cycles related to diatom blooms and possible, undesirable flagellate blooms 
rate constant for the process. In each case the flux may be represented by a term of the form $\mathrm{CV} / \tau$, where $c$ is the concentration of the nutrient involved in the process, $V$ the volume of water defining the nutrient pool or plankton bloom, and $\tau$ the time constant of the process.

A summary of these time constants is given in Table 2. In the original investigations from which these values were taken, rate coefficients $k$, or doubling times Tm, have sometimes been given. They have all been converted to time constants $\tau$, for convenience in comparison, by the usual relation $\tau=1 / k=T / 0.693$. The time constants for diatom production under opti-


(1929), Dugdale (1967), Eppley et al. (1969) and Parsons et al. (1961), those for flagellate production from Gran (1929), Dugdale (1967), Wilson et al. (1975), Kain and Fogg (1960) and Parsons et al. (1961). The time constants for silicon recycling through solution of diatom tests $\tau_{s}$ are all taken from Jorgensen (1955) and Lewin (1961). The time constants for nutrient recycling through diatom decomposition $\tau_{r T}$ are quoted from Riley et al. (1949).

Ryther and Dunstan (1971) as well as others argue that nitrogen, rather than phosphorus, is usually the limiting nutrient in marine phytoplankton growth. There is a sparsity of information on the time constants for nitrogen nutrient recycling through zooplankton grazing $\tau_{r z}$. The information does suggest that this is an important process for the regeneration of a nutrient supply for continued phytoplankton production and that this recycling process is rapid. Dugdale and Goering (1967) and Eppley et al. (1973) discuss the importance of this regeneration process in the euphotic zone of oceanic areas. Carpenter et al. (1969) argue that zooplankton grazing is the determining process for the continuation of the steady state phytoplankton population in Chesapeake Bay during the summer. From measurements of radiocarbon productivity they give a value of $0.2 \mathrm{mgl}^{-1} \mathrm{~d}^{-1}$ of organic carbon being produced in the euphotic zone during the summer, corresponding to an uptake of $4 \mu \mathrm{g}$ at $\mathrm{l}^{-1} \mathrm{~d}^{-1}$ of nitrogen. The steady state inorganic nitrogen concentration is $8 \mu \mathrm{g}$ at $1^{-1}$. Presuming that the cycling is entirely internal to the system with no external flux contribution and that steady state exists, $\tau_{r z}$ will be $2 \mathrm{~d}$. McCarthy et al. (1975) continued these investigations in more detail in Chesapeake Bay and conclude that the turnover time in the nutrient-phytoplankton-zooplankton-nutrient cycle is a day or less.

The values for the hydrodynamic residence time, or average lifetime of a conservative particle in a given body of water $\tau_{r n}$, are quoted from the summary in Officer and Ryther (1977). The quantity $\tau_{m}$ also is the time constant for a given body of water to regenerate to its steady state nutrient condition from a depleted, bloom, condition through the riverine and oceanic hydrodynamic nutrient fluxes into the region.

To gain some insight into the relative amount of

Table 2. Time constants, in days, for various marine environmental processes. $\tau_{p d}$ and $\tau_{p f}$. representative time constants for diatom and flagellate phytoplankton production, respectively, under optimum conditions. $x_{s}$ : time constant for silicon recycling from phytoplankton decomposition. $\tau_{r z}$ and $\tau_{r r}$ time constants for nitrogen and phosphorus recycling from zooplankton grazing and decomposition, respectively. $\tau_{m}$ : residence times for various riverine, estuarine and coastal water bodies

\begin{tabular}{|c|c|c|c|c|}
\hline \multicolumn{2}{|c|}{ Time constant } & \multirow{3}{*}{$\begin{array}{l}\text { Quantity } \\
\begin{array}{l}\text { Chaetoceros curvisetum } \\
\text { Skeletonema costatum }\end{array}\end{array}$} & Time constant & \multirow{2}{*}{$-\frac{\text { Quantity }}{\text { Chesapeake Bay }}$} \\
\hline$\tau_{p d}$ & $=0.4$ & & $\tau_{r z}=2.0$ & \\
\hline & $=0.2$ & & $=1.0$ & Chesapeake Bay \\
\hline & $=1.2$ & Rhizosolenia alata & & \\
\hline & $=0.6$ & Chaetoceros socialis & $\tau_{r r}=8.3$ & Natural Association \\
\hline & $=0.6$ & Skeletonema costatum & $=9.1$ & Natural Association \\
\hline & $=0.7$ & Ditylum brightwelli & $=12.5$ & Nitzschia closteriurn \\
\hline & $=2.2$ & Coscinodiscus sp. & $=13.3$ & Coscinodiscus sp. \\
\hline & $=1.4$ & Phaeodactylum tricornutum & $=9.1$ & Coscinodiscus sp. \\
\hline$\tau_{\mathrm{pf}}$ & $=4.8$ & Ceratium spp. & $\tau_{m}=8$ & Raritan River \\
\hline & $=2.9$ & Gonyaulax polyedra & $=56$ & Houston Ship Channel \\
\hline & $=3.3$ & Gymnodinium breve & $=28$ & Delaware River \\
\hline & $=3.3$ & Prorocentrum micans & $=2$ & Boston Harbor \\
\hline & $=0.5$ & Amphidinium carteri & $=4$ & Mersey Estuary \\
\hline & $=2.0$ & Exuviella sp. & $=14$ & Raritan Bay \\
\hline & $=0.5$ & Tetraselmis maculata & $=16$ & Passamaquoddy Bay \\
\hline & $=1.8$ & Isochrysis galbana & $=8$ & New York Bight \\
\hline & & & $=76$ & Bay of Fundy \\
\hline & $=110$ & Nitzchia linearis & & \\
\hline & $=190$ & Thalassiosira nana & & \\
\hline & $=45$ & Skeletonema chaetoceros & & \\
\hline & $=55$ & Thalassionema nitzchiodes & & \\
\hline
\end{tabular}


silicon available as compared with nitrogen availability in the second nutrient pool of Figure 1, we must compare the hydrodynamic nutrient fluxes (N, P, Si) with the recycling nutrient fluxes $(\mathrm{N}, \mathrm{P})$. The hydrodynamic flux will be given by a term of the form $F_{m}=c_{m}^{\cdot} V_{m} / \tau_{m}$, where $c_{m}^{*}$ is the steady state nutrient concentration in $V_{m}$ with no phytoplankton production; for a confined body of water or a large volume bloom region we would expect a large value for $\tau_{m}$. The recycling flux will be given by a term of the form $F_{r}=c_{r} V_{m} / \tau_{r}$ where $c_{r}$ is the concentration level involved in the recycling; the quantity $c_{r}$ will be less than $c_{r m}^{*}$ and will depend on the magnitude of the initial bloom in utilizing the available $c_{m}^{*}$ and on the efficiency of the recycling process. Thus, if $\tau_{m}$ is substantially greater than $\tau_{r^{\prime}}$ the second nutrient pool would be depleted in silicon and a flagellate bloom could be anticipated.

During the past decade, much emphasis has been given to studies of the nutrient uptake and growth kinetics of phytoplankton as functions of nutrient concentration. Half-saturation constants, or $K_{s^{\prime}}$ (the nutrient concentrations supporting half the maximum uptake or growth rate) have now been calculated for several nutrients and many algal species, using the Michaelis-Menton equation $v=V_{m} S /\left(K_{s}+S\right)$, where $v$ is the rate and $S$ is the concentration. These constants have been used to demonstrate the relative ability of different algal species to use low levels of nutrients and thereby to explain species succession or biogeographical distributional patterns of the phytoplankton.

A number of experimental studies have used silicon as the limiting nutrient (Guillard et al., 1973; Paasche, 1973a, b; Thomas and Dodson, 1975; Conway et al., 1976; Harrison et al., 1976; Conway and Harrison, 1977; Harrison et al., 1977; Tilman, 1977), most of which have shown mean half-saturation constants for several species of diatoms that range from about 0.5 to as much as $5.0 \mu \mathrm{g}$ at $~^{-1}$ of silicon, concentrations that are well within the range of both coastal and offshore surface values. As Paasche (1973b) points out, 'The rate of silicate uptake by plankton diatoms may become limited long before the supply of dissolved silicate in the sea water is exhausted, and low silicate concentrations may exert a selective influence on the species composition of phytoplankton populations in the sea.'

\section{OCEANIC EVIDENCE}

In the subtropical waters of the Sargasso Sea, thermal stratification of the upper $100 \mathrm{~m}$ during most of the year prevents the advection of deep, nutrient-rich water into the photosynthetic surface layers (Menzel and Ryther, 1960). The phytoplankters assimilate nu- trients from these waters and the latter are replenished mainly through the regenerative processes of excretion or decomposition of the plants or the animals of the plankton that eat them. Nitrogen and phosphorus are regenerated relatively quickly, but the siliceous tests of diatoms decompose more slowly and sink to subeuphotic depths before they are remineralized.

The phytoplankton of the Sargasso Sea near Bermuda is dominated by a flagellate community during most of the year, primarily by one species of the Coccolithophoridae, Coccolithus huxleyi, with smaller numbers of other coccolithophoridae and dinoflagellates. During April, the combination of winter cooling and spring-wind mixing is sufficient to effect some infusion of subeuphotic-depth water into the the surface layers and a brief but rather dramatic diatom bloom ensues. Twelve or more species of diatoms, most of which are never observed during the rest of the year, share dominance in this ephemeral bloom, which lasts no more than 1 to 2 weeks, and the community then reverts to the typical flagellate-dominated system with the resumption of thermal stratification and vertical stability (Hulburt et al., 1960).

Experiments in which samples of Sargasso Sea surface water were enriched with different nutrients and held in illuminated incubators for several days showed that addition of nitrogen and phosphorus alone resulted in growth of Coccolithus huxleyi and other flagellates while enrichment with $N, P$, and Si stimulated the growth of several species of diatoms to the virtual exclusion of flagellates (Menzel et al., 1963).

In certain parts of the oceans, the combination of winds and currents produce the phenomenon of coastal upwelling, in which surface waters are forced away from the shorelines and are replaced by nutrient-rich subsurface waters. Such regions, principally those off the west coasts of Africa and South America and the Antarctic continent, are biologically the most productive areas of the oceans. Normally producing a plankton flora dominated by a few species of large, colonial diatoms, these upwelling regions support some of the world's largest and most important fisheries (Ryther, 1969). However, when the upwelling system fails in these regions, due to a shift in the wind and/or currentregimes, the diatom blooms give way to a short-lived, predominantly dinoflagellate community (Brongersma-Sanders, 1948). The dinoflagellates appear not to be eaten by herbivorous fishes or other grazers, but sink and decompose in the subeuphotic layers and on the bottom, resulting in anoxic conditions, mass mortalities of fishes and benthic invertebrates, and the generation of hydrogen sulfide gas - the infamous 'Callao painter' that turns houses and boats black in that Peruvian coastal city during 'El Nino' years. The exact etiology of the transition from diatoms to 
dinoflagellates in these situations has never been well documented other than the fact that it is associated with the cessation of upwelling. The presumption is strong, however, of a highly productive organic system whose nutrient supply is suddenly cut off and which can continue to function temporarily only through regeneration of the more rapidly recycled elements, resulting in a shift in community structure.

\section{COASTAL AND ESTUARINE EVIDENCE}

Northern San Francisco Bay typically has a single summer-fall peak in phytoplankton abundance and productivity that is dominated by neritic diatoms (Cloern, 1978). Conomos and Peterson (1975) and Peterson and Conomos (1975) have studied the relationship between phytoplankton growth and nutrient availability in the Northern San Francisco Bay region during 1972.

The nutrients were utilized to varying degrees during the summer bloom period of 1972. Silicate utilization was most dramatic with decreases ranging from 150 to $180 \mu \mathrm{g} \mathrm{l}^{-1}$, representing utilization of $80 \%$ of the available silicate. Virtually all the nitrate and nitrite was depleted, decreasing concentrations by an amount of 10 to $16 \mu \mathrm{g}$ at $\mathrm{l}^{-1}$ to levels of less than $1 \mu \mathrm{g}$ at $\mathrm{l}^{-1}$. Ammonia utilization was similar, decreasing concentrations by about $1 \mu \mathrm{g}$ at $1^{-1}$ to levels of less than $1 \mu \mathrm{g}$ at $\mathrm{l}^{-1}$. Almost half the available phosphate was utilized, decreasing concentrations by an amount of about 1.6 $\mu \mathrm{g}$ at $\mathrm{l}^{-1}$. It would appear, as we might have expected, that there is rapid recycling of the nitrogen to accommodate the substantial decrease in silicon on an approximate one-to-one atom basis in diatom production.

D. H. Peterson (personal communication) states that San Francisco Bay does not at present have excessive or undesirable phytoplankton concentrations or conditions that might lead to the development of predominantly nuisance species or to serious dissolved oxygen deficiencies except locally, as in tributary streams along the margins. He cautions, however, that a significant reduction in the amount of available silicate that would accompany large scale diversions of freshwater inflow could alter this situation.

The Hudson Estuary and New York Bight region provide an interesting contrast with San Francisco Bay. Both are areas which have substantial nutrient pools of nitrogen and phosphorus provided from river runoff and municipal, industrial and agricultural discharges. In the case of San Francisco Bay there is an abundant supply of silicon, and diatoms are the dominant phytoplankton. In the case of the New York Bight there is an impoverished supply of silicon.

Garside et al. (1976) discuss the sewage-derived nutrient inputs to the Hudson Estuary. They compare the observed nutrient concentrations of the effluent from the secondary treatment plant at Tallman Island as given in Table 1 with 'typical' values of 1420,656 and $264 \mu \mathrm{g}$ at $\mathrm{l}^{-1}$ for nitrogen, silicon and phosphorus, respectively, for a secondary treated sewage from Weinberger et al. (1966). The impoverishment of inorganic silicon with respect to inorganic nitrogen for the New York City effluent should be noted. They estimate that 160 metric tons of nitrogen are released each day into the New York waterways from the sewage effluents and that $117 \mathrm{t} \mathrm{d}^{-1}$ exit from the Hudson Estuary to the New York Bight during the summer.

Simpson et al. (1977) investigated the silicate distribution in the Hudson Estuary. They conclude that there is a substantial uptake of dissolved silicate during the summer from diatom production with consequent loss of silicon to the estuarine waters and that the nutrients nitrogen and phosphorus are recycled rapidly in contrast to the much slower regeneration rate for silicon. At the lower end of the Hudson Estuary the silicon levels are around $10 \mu \mathrm{g}$ at $\mathrm{l}^{-1}$ or less during the summer.

Malone (1976) examined the nutrient concentrations and phytoplankton productivity in the New York Bight adjacent to the mouth of the Hudson Estuary from September, 1973, through August, 1974. From February to August the dissolved inorganic nitrogen concentration decreased from $10 \mu \mathrm{g}$ at $\mathrm{l}^{-1}$ to $2 \mu \mathrm{g}$ at $\mathrm{l}^{-1}$. From February to March the dissolved silicon levels decreased from $2 \mu \mathrm{g}$ at $\mathrm{l}^{-1}$ to $1 \mu \mathrm{g}$ at $\mathrm{l}^{-1}$ or less, remained at these levels during the spring and early summer, and increased to $2 \mu \mathrm{g}$ at $\mathrm{l}^{-1}$ from July to August. The netplankton productivity peaked in February $(1.7 \mathrm{~g} \mathrm{C}$ $\left.\mathrm{m}^{-2} \mathrm{~d}^{-1}\right)$ and June $\left(2.2 \mathrm{~g} \mathrm{C} \mathrm{m}^{-2} \mathrm{~d}^{-1}\right)$; nanoplankton productivity was highest in June $\left(2.1 \mathrm{~g} \mathrm{C} \mathrm{m}^{-2} \mathrm{~d}^{-1}\right)$ and July $\left(3.7 \mathrm{~g} \mathrm{C} \mathrm{m}^{-2} \mathrm{~d}^{-1}\right)$. The February peak was dominated by the diatom Skeletonema costatum, and the summer phytoplankton was dominated by the nonmotile green alga Nannochloris atomus.

It would appear from these investigations that there is an abundant supply of the nutrients nitrogen and phosphorus exiting from the Hudson Estuary to the New York Bight and a depleted supply of the nutrient silicon, conditions favorable for a flagellate bloom with consequent undesirable eutrophication effects. During the summer and fall of 1976 an anoxic condition occurred off the coast of New Jersey covering an area of approximately $180 \mathrm{~km}$ by $90 \mathrm{~km}$ on the continental shelf with dissolved oxygen levels of $2 \mathrm{mg} \mathrm{l}^{-1}$ or less As discussed in Sharp (1976), the anoxia was related to the sinking and consequent respiration and decay of an extensive bloom of the dinoflagellate Ceratium tripos. During this period the surface waters, down to about $15 \mathrm{~m}$, were relatively clear. The bottom waters were described as being very dark with powerful lights 
required even at midday to clearly distinguish objects on the bottom. Dark colored, stringy particles were reported present in this bottom water with accumulations of more than $1 \mathrm{~cm}$ of a dark, loose material covering most of the bottom. One commercial trawler reported collecting dead fish, up to $75 \%$ of his catch, in $50 \mathrm{~m}$ of water in the area during this period.

As discussed by Jaworski et al. (1972), as well as others, the region ot the Potomac Estuary in the vicinity of Washington suffers from large nuisance populations of the blue-green algae Anacystis sp. during the summer. At times large populations of the red tide dinoflagellates Gymnodinium sp. and Amphidinium sp. occur. The occurrence of a spring bloom of diatoms is also common. There is an abundant supply of all nutrients to the Potomac from sewage effluents and river runoff. D. H. Peterson (personal communication) of the US Geological Survey investigated the dissolved silicate distribution in the Potomac Estuary during the late summer of 1977 . In the vicinity of the algal bloom region south of Washington he obtained levels of around $3 \mu \mathrm{g}$ at $\mathrm{l}^{-1}$ or less of dissolved silicate; further downestuary away from the bloom region the silicate concentrations showed a striking increase to levels of around $80 \mu \mathrm{g} \mathrm{at}^{-1}$. We suggest that the silicon in the bloom area was removed during the spring diatom bloom and that the recycled nitrogen and phosphorus provided the nutrient pool for the summer algal bloom.

Pratt (1965) made weekly observations of phosphate, nitrate, silicate and phytoplankton in Narragansett Bay, Rhode Island over a $41 / 2$ year period in an attempt to understand year-to-year variations in the time of inseption and magnitude of the winter-spring diatom flowering that is indigenous to the area. He concluded, "The silicate supply appears to be critical as the annual diatom maximum is reached. Not only is the magnitude of this maximum a function of the initial silicate concentrations but - growth was never observed to continue after silicate depletion, and in seven of the twelve instances, the population reached its maximum just as silicate approximated zero and decreased sharply the following week.

Parsons et al. (1978) attempted to explain observed sequences of diatom and flagellate blooms in a large controlled ecosystem enclosure (CEE) located in Saanich Inlet, B. C. over a period of $60 \mathrm{~d}$ on the basis of the interaction of light intensity, nitrogen and silicon. While many factors, acting independently and/or cumulatively undoubtedly may influence phytoplankton species succession and dominance in nature, the striking inverse correlation between silicate and diatoms alone would appear to be quite adequate to explain the observed species shifts in that particular case (Fig . 2). Similarly, the reported selective effects of copper toxicity on diatoms and flagellates in the same

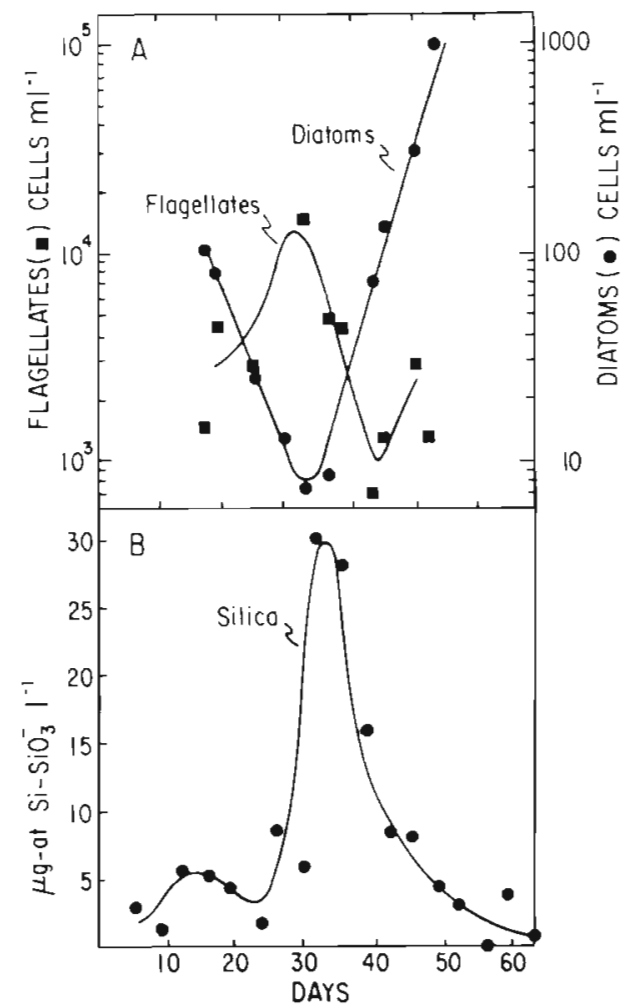

Fig. 2. (A) Changes in number of diatoms (•) and flagellates ( $)$ in CEE experiment. (B) Changes in silicate concentration in same

CEE system (Thomas and Seibert, 1977) would seem, in the absence of evidence to the contrary, equally likely to have resulted from silicon depletion following the growth and sedimentation of the initial diatom population.

Other coastal and estuarine regions which suffer eutrophication effects do not, to our knowledge, have sufficient information on both phytoplankton populations and nutrients, particularly silicon, to establish the possible importance of silicon, or not, as a control.

\section{LIMNOLOGICAL EVIDENCE}

The importance of silicon as a controlling nutrient in the growth of freshwater phytoplankton has been studied in some detail. Kilham (1971) has critically examined the literature to relate ambient silica concentrations to numerical dominance of specific freshwater planktonic diatoms. Mean silica concentrations in $\mu \mathrm{g}$ at $\mathrm{l}^{-1}$ of silicon during dominance were 10 for Stephanodiscus astraea, 15 for Tabellaria flocculosa asterionelloides, 23 for Asterionella formosa, and 223 for Melosira granulata. The concentration at the time of dominance and the patterns of diatom periodicity observed in the several eutrophic lakes covered in his 
literature survey led Kilham to the hypothesis that declining ambient silica concentrations may influence the sequence of seasonal succession of diatom populations. He goes on to conclude that when the silica demand is high and available silica becomes depleted, diatoms become scarce and are ultimately replaced by green and blue-green algae. He suggests, in much the same manner as we do, that some measure of silica demand could be used as an index of increasing eutrophication.

Schelske and Stoermer (1971 and 1972), Schelske et al. (1971) and Schelske (1975) have made a throughtful study of the silica budget and its possible importance in accelerated eutrophication in Lake Michigan. Lake Michigan provides an interesting contrast with the examples from oceanic and coastal and estuarine areas, for the hydrodynamic residence time of the lake is of the order of 30 years (Rainey, 1967). Silica depletion within the lake as a whole can, then, be examined on a longer, year-to-year time scale to examine what effects increased anthropogenic nutrient inputs with their resultant summer phytoplankton blooms have had on the silica budget in the lake as a whole.

In lakes, in contrast to marine areas, phosphorus, rather than nitrogen, is usually the limiting nutrient for phytoplankton growth. Schelske (1975) examined the nutrient inputs to Lake Michigan. For the unpolluted tributaries silica supplies are greater relative to supplies of phosphorus than the proportions required for freshwater diatom growth. For the polluted tributaries, which provide the bulk of the phosphorus input, silica supplies are smaller relative to supplies of phosphorus than the proportions required for diatom growth. For continued diatom production during the summer demand will be made on the lake reservoir of silica until such time as the supplies of silica are limited, and the excess supplies of phosphorus can then be used by green and blue-green algae.

The lake silica reservoir has been depleted within historical time. Schelske and Stoermer (1971 and 1972) point out from chemical data collected near Chicago that the yearly average concentration of silica has decreased by at least $70 \mu \mathrm{g}$ at $\mathrm{l}^{-1}$ of silicon in the last 44 years. In 1926 values of 80 and $100 \mu \mathrm{g} \mathrm{at}^{-1}$ were reported. More recent data show that the decrease is general over the lake and not restricted to nearshore waters. Concentrations of silicon in surface waters were less than $42 \mu \mathrm{g}$ at $\mathrm{l}^{-1}$ over most of Lake Michigan and less than $17 \mu \mathrm{g}$ at $\mathrm{l}^{-1}$ near Chicago in August, 1955. Fourteen years later silicon averaged $2.5 \mu \mathrm{g}$ at $\mathrm{l}^{-1}$ during July in the southern basin and $4.3 \mu \mathrm{g}$ at $\mathrm{I}^{-1}$ in the northern basin of Lake Michigan.

They conclude that accelerated eutrophication by pollution inputs of phosphorus is causing silica depletion in the waters of the lake. They go on to speculate that limitation of the reproduction of the presently dominant diatom population, which requires silica, may lead to drastic and, on the whole, undesirable changes in the ecosystem. They point out that such changes are now taking place. Phytoplankton samples collected in 1969 during the end of the summer growth period indicate that diatoms have been replaced by blue-green and green algae. Blue-green and green algae comprised from 56 to $85 \%$ of the total cell counts in late August and early September and from 30 to $45 \%$ of the total cell counts in late September.

Conway et al. (1977) point out that the depletion of silicon in the surface layers of Lake Michigan is actually a seasonal phenomenon, much of that lost to the water column each spring and early summer by the sinking of diatom tests and copepod fecal pellets containing them being recycled the following winter and thereby supporting an annual spring diatom bloom. This is hardly a new observation, having been reported in English lakes by Pearsall (1932) and later by Lund (1950), both of whom noted a rapid depletion of diatoms with a drop of silicon below $8 \mu \mathrm{g}$ at $\mathrm{l}^{-1}$. The significance of the Schelske and Stoermer investigations is not the description of the present annual cycle of diatoms followed by other kinds of algae, the normal sequence of events in many freshwater and marine areas, but rather their documentation of the historical depletion of the silicon reserve from the waters of Lake Michigan, formerly a surplus sufficient to maintain diatoms throughout the year, as a result of the addition of an allochthonous nutrient supply poor in silicate.

The investigations by Schelske and Stoermer provide a most convincing argument of the importance of silicon as a control in marine eutrophication in determining the changes from a diatom, and generally desirable, phytoplankton population to a flagellate, and generally undesirable, population.

\section{CONCLUSIONS}

Arguments have been presented as to the importance of the nutrient silicon in altering a generally desirable, diatom phytoplankton population to a frequently undesirable, flagellate phytoplankton population and consequent eutrophication effects. If these arguments are accepted, several possible conclusions follow. We mention three. One, rather than considering treatment procedures which remove the nutrients nitrogen and phosphorus from a sewage discharge into a eutrophied region, one might consider the addition, if feasible, of silica in quantity at the discharge site to alter the receiving waters to a diatom population and a consequent fertile and productive region. Two , regions with substantial natural silica inputs can toler- 
ate larger sewage inputs of nitrogen and phosphorus before undesirable eutrophication effects occur. Three, as in Lake Michigan silica measurements are a critical key to the determination of the onset of undesirable eutrophication effects.

Acknowledgements. Our interest in the subject covered in this article was stimulated through discussions with $\mathrm{H}$. Curl, J. M. Demanche, R. C. Dugdale, E. A. Jenne, D. P. Larsen and R. Lasker at the National Oceanic and Atmospheric Administration sponsored workshop on ocean pollution of July, 1978.

\section{LITERATURE CITED}

Brand, L. E. (1979). Unpublished data, Woods Hole Oceanographic Institution, Woods Hole

Brongersma-Sanders, M. (1948). The importance of upwelling water to vertebrate paleontology and oil geology. Verhand. Konin. Nederland. Akad. Wetenschap Natuur., Tweede Sectic 45 (4): 1-112

Carpenter, J. H., Pritchard, D. W., Whaley, R. C. (1969). Observations of eutrophication and nutrient cycles in some coastal plain estuaries. In: Eutrophication: causes, consequences, corrections. National Academy of Sciences, Washington, pp. 210-221

Cloern, J. E. (1979). Empirical model of Skeletonema costatum photosynthetic rate with applications in the San Francisco Bay estuary. Adv. Wat. Res. 1: 267-273

Conomos, T. J., Peterson, D. H. (1975). Longitudinal distribution of selected micronutrients in Northern San Francisco Bay during 1972. In: Brown, R. L. (ed.) Proceedings of a workshop on algae nutrient relationships in the San Francisco Bay and delta. Department of Water Resources, California, pp. 103-126

Conway, H. L., Harrison, P. J. (1977). Marine diatoms grown in chemostats under silicate or ammonium limitation. IV. Transient response of Chaetoceros debilis, Skeletonema costatum and Thalassiosira gravida. Mar. Biol. 43: 33-43

Conway, H. L., Harrison, P. J., Davis, C. O. (1976). Marine diatoms grown in chemostats under silicate or ammonium limitation. II. Transient response of Skeletonema costatum to a single addition of the limiting nutrient. Mar. Biol. 35: 187-199

Conway, H. L., Parker, J. I., Yaguchi, E. M., Mellinger, D. L. (1977). Biological utilization of silicon in Lake Michigan. J. Fish. Res. Bd Can. 34: 537-544

Dugdale, R. C. (1957). Nutrient limitation in the sea: dynamics, identification and significance. Limnol. Oceanogr. 12: 685-695

Dugdale, R. C., Goering, J. J. (1967). Uptake of new and regenerated forms of nitrogen in primary productivity. Limnol. Oceanogr. 12: 196-206

Dunstan, W. M., Tenore, K. R. (1972). Intensive outdoor culture of marine phytoplankton enriched with treated sewage effluent. Aquaculture 1: 181-192

Eppley, R. W., Renger, E. H., Vendrik, E. L., Mullin, M. M. (1973). A study of the plankton dynamics and nutrient cycling in the central gyre of the North Pacific Ocean. Limnol. Oceanogr. 18: 534-551

Eppley, R. W., Rogers, J. N., McCarthy, J. J. (1969). Half saturation constants for uptake of nitrate and ammonium by marine phytoplankton. Limnol. Oceanogr. 14: 912-920
Garside, C., Malone, T. C., Roels, O. A., Sharfstein, B. A (1976). An evaluation of sewage derived nutrients and their influence on the Hudson Estuary and New York Bight. Estuar. \& coast. mar. Sci. 4: 281-289

Gran, H. H. (1929). Investigation of the production of plankton outside the Romsdalsfjord 1926-1927. Rapp. P.-v. Réun. Cons. int. Explor. Mer 56: 1-15

Guillard, R. R. L., Kilham, P., Jackson, T. A. (1973). Kinetics of silicon limited growth in the marine diatom Thalassiosira pseudonana Hasle and Heimdal (= Cyclotella nana Heustedt). J. Phycol. 9: 233-237

Harrison, P. J., Conway, H. L., Dugdale, R. C. (1976). Marine diatoms grown in chemostats under silicate or ammonium limitation. I. Cellular chemical composition and steady state growth kinetics of Skeletonema costatum. Mar. Biol. 35: $177-186$

Harrison, P. J., Conway, H. L., Holmer, R. W., Davis, C. O. (1977). Marine diatoms grown in chemostats under silicate or ammonium limitation. III. Cellular chemical composition and morphology of Chaetoceros debilis, Skeletonema costatum and Thalassiosira gravida. Mar. Biol. 43: 19-31

Hulburt, E. M., Ryther, J. H., Guillard, R. R. L. (1960). The phytoplankton of the Sargasso Sea off Bermuda. J. Cons. int. Explor. Mer 25: 115-128

Jaworski, N. A., Lear, D. W., Villa, O. (1972). Nutrient management in the Potomac Estuary. In: Likens, G. E. (ed.) Nutrients and eutrophication. American Society of Limnology and Oceanography, Lawrence, pp. 246-273

Jitts, H. R., McAllister, C. D., Stephans, K., Strickland, J. D. N. (1964). The cell division rates of some marine phytoplankton as a function of light and temperature. J. Fish. Res. Bd Can. 21: 139-157

Jorgensen, E. G. (1955). Solubility of the silica in diatoms. Physiologia Pl. 8: 846-851

Kain, J. M., Fogg, G. E. (1960). Studies on the growth of marine phytoplankton. III. Prorocentrum micans Ehrenberg. J. mar. biol. Ass. U. K. 39: 33-50

Kilham, P. (1971). A hypothesis concerning silica and the freshwater planktonic diatoms. Limnol. Oceanogr. 16: $10-18$

Lewin, J. (1961). The dissolution of silica from diatom walls. Geochim. cosmochim. Acta 21: 182-198

Lund, J. W. G. (1950). Studies on Asterionella formosa Haas. II. Nutrient depletion and the spring maximum. J. Ecol. 38: $1-35$

Malone, T. C. (1976). Phytoplankton productivity in the apex of the New York Bight: environmental regulation of productivity/chlorophyll a. In: Gross, M. G. (ed.) Middle Atlantic continental shelf and the New York Bight. American Society of Limnology and Oceanography, Lawrence, pp. $260-272$

Margalef, M. (1958). Temporal succession and spatial heterogeneity in phytoplankton. In: Buzzati-Traverso, A. A.(ed.) Perspectives in marine biology. University of California Press, Berkeley, pp. 323-349

McCarthy, J. J., Taylor, W. R., Taft, J. L. (1975). The dynamics of nitrogen and phosphorus cycling in the open waters of the Chesapeake Bay. In: Church, T. M. (ed.) Marine chemistry in the coastal environment. American Chemical Society, Washington, pp. 664-681

Menzel, D. W., Hulburt, E. M., Ryther, J. H. (1963). The effects of enriching Sargasso Sea water on the production and species composition of the phytoplankton. Deep Sea Res. 10: $209-219$

Menzel, D. W., Ryther, J. H. (1960). The annual cycle of primary production in the Sargasso Sea off Bermuda. Deep Sea Res. 6: 351-367 
Officer, C. B., Ryther, J. H. (1977). Secondary sewage treatment versus ocean outfalls: An assessment. Science, N. Y. 197: 1056-1060

Paasche, E. (1973a). Silicon and the marine ecology of marine plankton diatoms. I. Thalassiosira pseudonana (Cyclotella nana) grown in a chemostat with silicate as a limiting nutrient. Mar. Biol. 19: 117-126

Paasche, E. (1973b). Silicon and the ecology of marine plankton diatoms. II. Silicate uptake kinetics in five diatom species. Mar. Biol. 19: 262-269

Parsons, T. R., Harrison, P. J., Waters, R. (1978). An experimental simulation of changes in diatom and flagellate blooms. J. exp. mar. Biol. Ecol. 32: 285-294

Parsons, T. R., Stephens, K., Strickland, J. D. H. (1961). On the chemical composition of eleven species of marine phytoplankters. J. Fish. Res. Bd Can. 18: 1003-1020

Pearsall, W. H. (1932). Phytoplankton of the English Lakes. 2. The composition of the phytoplankton in relation to disolved substances. J. Ecol. 20: 241-262

Peterson, D. H., Conomos, T. J. (1975). Implications of seasonal chemical and physical factors on the production of phytoplankton in Northern San Francisco Bay. In: Brown, R. L. (ed.) Proceedings of a workshop on algae nutrient relationships in the San Francisco Bay and delta. Department of Water Resources, California, pp. 147-166

Pratt, D. M. (1965). The winter-spring diatom flowering in Narragansett Bay, Limnol. Oceanogr. 10: 173-184

Rainey, R. H. (1967). Natural displacement of pollution from the Great Lakes. Science, N. Y. 155: 1242

Redfield, A. C., Ketchum, B. H., Richards, F. A. (1963). The influence of organisms on the composition of sea water. In: Hill, M. N. (ed.) The sea, Vol. II. John Wiley, New York, pp. 26-77

Riley, G. A., Stommel, H., Bumpus, D. F. (1949). Quantitative ecology of the western North Atlantic. Bull. Bingham oceanogr. Coll. 12: 1-169

Ryther, J. H. (1969). Photosynthesis and fish production in the sea. Science, N. Y. 166: 72-76

Ryther, J. H. (1977). Unpublished data, Woods Hole Oceanographic Institution, Woods Hole

Ryther, J. H., Dunstan, W. M. (1971). Nitrogen, phosphorus and eutrophication in the coastal marine environment. Science, N. Y. 171: 1008-1013

Schelske, C. L. (1975). Silica and nitrate depletion as related to rate of eutrophication in Lakes Michigan, Huron and Superior. In: Hasler, A. D. (ed.) Coupling of land and water systems. Springer-Verlag, New York, pp. 277-298

Schelske, C. L., Stoermer, E. F. (1971). Eutrophication, silica depletion and predicted changes in algal quality in Lake Michigan. Science, N. Y. 173: 423-424

Schelske, C. L., Stoermer, E. F. (1972). Phosphorus, silica and eutrophication in Lake Michigan. In: Likens, G. E. (ed.) Nutrients and eutrophication. American Society of Limnology and Oceanography, Lawrence, pp. 157-171

Schelske, C. L., Stoemer, E. F., Feldt, L. E. (1971). Nutrients, phytoplankton productivity and species composition as influenced by upwelling in Lake Michigan. In: Proceedings of the Fourteenth Conference on Great Lakes Research. International Association for Great Lakes Research, Ann Arbor

Sharp, J. H. (ed.) (1979). Anoxia on the Middle Atlantic shelf during the Summer of 1976. National Science Foundation, Washington

Simpson, H. J., Williams, S. C., Olsen, C. R., Hammond, D. E. (1977). Nutrient and particulate matter budgets in urban estuaries. In: Estuaries, geophysics and the environment. National Academy of Sciences, Washington, pp. 94-103

Thomas, W. H., Dodson, A. N. (1975), On silicic acid limitation of diatoms in near surface waters of the eastern tropical Pacific Ocean. Deep Sea Res. 22: 671-677

Thomas, W. H., Seibert, D. L. R. (1977). Effects of copper on the dominance and diversity of algae: controlled ecosystem pollution experiment. Mar. Sci. 27: 23-33

Thomas, W. H., Dodson, A. W., Reid, F. M. H. (1978). Diatom productivity compared to other algae in natural marine phytoplankton assemblages. J. Phycol. 14: 250-253

Tilman, D. (1977). Resource competition between planktonic algae: an experimental and theoretical approach. Ecology 58: $338-348$

Weinberger, L. W., Stephens, D. G., Middleton, F. M. (1966). Solving our water problems - water renovation and reuse. Ann. N.Y. Acad. Sci. 136: 131-154

Wilson W. B., Ray, S. M., Aldrich, D. V. (1975). Gymnodinium breve: population growth and development of toxicity in cultures. In: Cicereo, V. R. (ed.) Proceedings of the first international conference on toxic dinoflagellate blooms. The Massachusetts Science and Technology Foundation, Wakefield, pp. 127-141 